\title{
Пандемія COVID-19 (штами «Дельта», «Омікрон»): особливості навчання на тематичному циклі «Загальна фармація на засадах фармацевтичного права»
}

\author{
The COVID-19 Pandemic (Strains "Delta", "Omicron"): Particularities of \\ Study on the Thematic Cycle "General Pharmacy Based on Pharmaceutical \\ Law"
}

Вікторія Шаповалова (Viktoriia Shapovalova), доктор фармацевтичних наук, професор, Харківська медична академія післядипломної освіти, Харків, Україна; Валерій Шаповалов (Valerii Shapovalov), доктор фармацевтичних наук, професор, ТзОВ «Львівський медичний інститут», Львів, Україна; Валентин Шаповалов (Valentyn Shapovalov), доктор фармацевтичних наук, професор, Адвокатське об'єднання «Апофеоз», Харків, Україна; Аліна Осинцева (Alina Osyntseva), кандидат фармацевтичних наук, Харківська медична академія післядипломної освіти, Харків, Україна; Сергій Негрецький (Serhii Negretskii), кандидат фармацевтичних наук, Харківська медична академія післядипломної освіти, Харків, Україна; Анатолій Деркач (Anatolii Derkach), кандидат фармацевтичних наук, доцент, Харківська медична академія післядипломної освіти, Харків, Україна; Олександр Січкаренко (Oleksandr Sichkarenko), Харківська медична академія післядипломної освіти, Харків, Україна.

Вступ. Карантинні обмеження, що встановлено в державі взагалі, у м. Львів, м. Харків, м. Київ зокрема, внаслідок розповсюдження пандемії на COVID-19 (штами «Дельта», «Омікрон») вплинули на організацію роботи в аптеках, закладах охорони здоров'я, всього медперсоналу в системі правовідносин «лікар-пацієнт-провізор». З'явилися особливі обмеження (масковий режим, ПЦР-тести, вимоги до щеплення тощо), обмеження планових операцій - оперативних втручань, внаслідок чого значно зменшилися (а подекуди взагалі відмінили) потоки планових пацієнтів [1]. Під час піку пандемії були залучені лікарі-інтерни, яких направляли до центрів терапії на допомогу практичним лікарям, які працювали з пацієнтами у «червоних зонах», оскільки в них знаходилася велика кількість пацієнтів (IВЛ тощо) та практичним лікарям потрібна була допомога. Лікарі-інтерни, що знаходилися в таких умовах розуміли, що їх завдання допомагати як лікарям, та і хворим. Навчання інтернів складалося 3 двох частин: спеціалізація на базі закладу охорони здоров'я чи аптеки; навчання на базі вищого навчального закладу (лекції, семінарські заняття тощо). Міністерство охорони здоров'я України наголосило, що через напружену ситуацію, яка склалася в закладах охорони здоров'я із госпіталізацією хворих на COVID-19, а також значне зростання навантаження на медиків, MO3 України розглядає можливість залучення до боротьби під час пандемії лікарів-інтернів і студентів 5-6 курсу навчання у вищих навчальних медичних закладах. Також було роз'яснено, що інтерни та студенти можуть брати участь у процесі лікування хворих виключно під контролем кваліфікованих лікарів [2].

Одним 3 дієвих методів розв'язання проблем та викликів пандемії має стати підвищення конкурентоспроможності навчання за рахунок підвищення 
якості он-лайн освіти [3]. Вплив змін сучасності на освітній процес має відбуватися за рахунок впровадження нових форм та нових форматів віртуальної освіти, розробки антикризових заходів сумісно з міжнародними партнерами. Необхідно проведення тренінгів та семінарів для викладачів 3 метою підвищення майстерності роботи на нових інформаційних платформах. Підвищенню якості освіти повинно сприяти також формування он-лайн спільнот студентів та викладачів для зниження тиску ізоляції та подолання психологічного стресу. Гідне фінансування дозволить покращити інфраструктуру вишів для викладання в он-лайн форматі та забезпечить достатню потужність освітнього процесу навіть в умовах триваючої пандемії. Немає сумнівів, що пандемія та iï наслідки істотно змінять наш звичний світ, але ми повинні зробити все можливе для того, щоб уникнути втрат національного інтелектуального потенціалу та підвищити якість освіти до світового рівня. Тільки розробка та просування національної стратегії вищої освіти 3 урахуванням світового досвіду здатна підвищити конкурентоспроможність вузів Україні на світовому освітньому ринку та задовольнити потреби національного та загальносвітового ринку праці.

Програмне забезпечення, яке використовує кафедра медичного та фармацевтичного права, загальної і клінічної фармації (далі - Кафедра) Харківської медичної академії післядипломної освіти (ХМАПО) під час проведення навчання на тематичному циклі «Загальна фармація на засадах фармацевтичного права» для провізорів під час пандемії COVID-19 (штами «Дельта», «Омікрон») називається Moodle (Рис. 1).
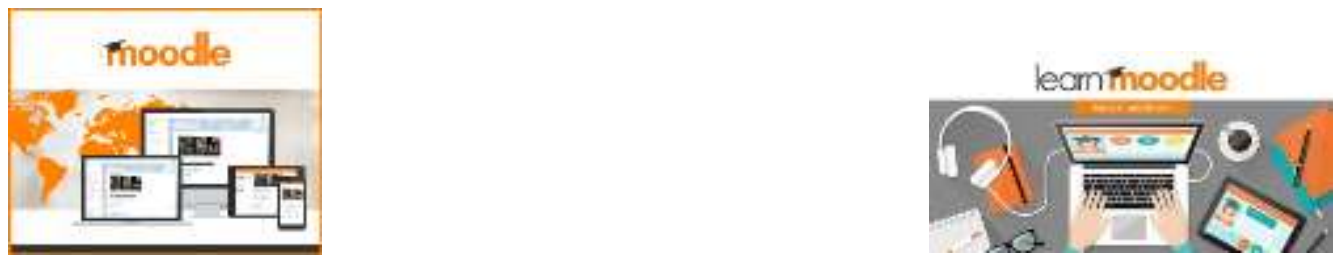

Рис. 1. Логотипи платформи Moodle

Moodle (Modular Object-Oriented Dynamic Learning Environment, вимовляється «Мудл») - це модульне об'єктно-орієнтоване динамічне навчальне середовище, яке називають також системою управління навчанням (LMS), системою управління курсами (CMS), віртуальним навчальним середовищем (VLE) або просто платформою для навчання, яка надає викладачам, учням та адміністраторам дуже розвинутий набір інструментів для комп'ютеризованого навчання, в тому числі дистанційного. Moodle можна використовувати в навчанні школярів, студентів, при підвищенні кваліфікації, бізнес-навчанні, як в комп'ютерних класах навчального закладу, так і для самостійної роботи вдома [4].

Moodle - це безкоштовна, відкрита (Open Source) система. Вона не лише безкоштовна сама, а й не потребує для своєї роботи жодного платного програмного забезпечення. Тобто кожний навчальний заклад може впровадити 
у себе не просто безкоштовну і найбільш досконалу, а ще й абсолютно ліцензійну систему, не витративши жодної копійки на придбання програмного забезпечення. При цьому він може вносити зміни у код у відповідності до своїх потреб. Moodle - це найбільш досконала і поширена в Україні і в світі система такого призначення. На даний момент Moodle вже має 129 мільйонів користувачів в усьому світі й продовжує розвиватися темпами, значно швидшими, ніж іï конкуренти. У 2018 р. за статистикою, використання платформи Moodle у світі перевищило використання усіх інших платформ разом узятих. Moodle (модульне об'єктно-орієнтоване динамічне навчальне середовище) - вільно-поширювана австралійська система управління навчанням. Система орієнтована, перш за все, на організацію взаємодії між науково-педагогічними працівниками (НПП) і слухачами, хоча підходить і для організації традиційних дистанційних курсів, а також підтримки денної та заочної форм навчання слухачів (студентів). Отже, користувачами Moodle 3 однієї сторони є курсанти, студенти (далі - слухачі), а з іншої сторони - НПП, які розробляють та супроводжують дистанційні курси [5].

При створенні курсу в нього автоматично включається тільки «Новий форум». Moodle має у своєму розпорядженні більшу різноманітність модулів (елементів курсу), які можуть бути використані для створення курсів будьякого типу. Залежно від змісту курсу й концепції викладання автор курсу включає найбільш підходящі елементи та ресурси, що надаються системою Moodle. Можна розділити інструменти (модулі) Moodle для викладення матеріалів курсу на статичні (ресурси курсу) і інтерактивні (елементи курсу).

До статичних (ресурси курсу) відносяться: • текстова сторінка; • вебсторінка; • посилання на файл або веб-сторінку; • посилання на каталог; • пояснення - дозволяє додавати текст і графіку на головну сторінку курсу. За допомогою такого напису можна пояснити призначення якої-небудь теми, тижня або використовуваного інструмента.

До інтерактивних (елементи курсу) відносяться:

- елемент Лекція - будується за принципом чергування сторінок з теоретичним матеріалом і сторінок 3 навчальними тестовими завданнями й питаннями. Послідовність переходів зі сторінки на сторінку заздалегідь визначається викладачем - автором курсу і залежить від того, як слухач відповідає на запитання. На неправильні відповіді викладач може дати відповідний коментар; - елемент Завдання - дозволяє НПП ставити завдання, які вимагають від слухачів відповіді в електронній формі (у будь-якому форматі), і дає можливість завантажити його на сервер. Елемент Завдання дозволяє оцінювати отримані відповіді;

- елемент Тест - дозволяє створювати набори тестових завдань. Тестові завдання можуть бути 3 декількома варіантами відповідей, 3 вибором правильно/неправильно, що припускають коротку текстову відповідь, на відповідність, есе та інше. Усі питання зберігаються в базі даних і можуть бути використані знову в цьому ж курсі (або в інших). Тести можуть бути 
навчальними (показувати правильні відповіді) або контрольними (повідомляти тільки оцінку);

- елемент Wiki - дає можливість спільно працювати над вивченням документів. Будь-який учасник курсу може редагувати wiki-статті. Всі виправлення wikiстатей зберігаються в базі даних, можна запитувати будьякий минулий варіант статті або для порівняння різницю між будь-якими 12 двома минулими варіантами статей за допомогою посилання «Останні виправлення». Використовуючи інструментарій Wiki, слухачі працюють разом над редагуванням однієї wiki-статті, відновленням і зміною iii змісту. Редактор, вбудований у Wiki, дозволяє вставляти в текст статті таблиці, малюнки й формули. Залежно від налаштувань групової роботи Moodle може містити в собі дванадцять різних wiki-редакторів. При колективній роботі НПП, використовуючи функцію «Історія», може відстежити внесок кожного учасника в створенні статті й оцінити його;

- елемент Глосарій - дозволяє створювати й редагувати список визначень, як у словнику. Наявність глосарія, що пояснює ключові терміни, ужиті в навчальному курсі, просто необхідна в умовах позаудиторної самостійної роботи. Елемент Глосарій полегшує НПП завдання створення подібного словника термінів. Глосарій може бути відкритий для створення нових записів (статей) не тільки для викладача, але й для слухачів;

- елемент Форум - використовується для організації дискусії й групується по темах. Після створення теми кожний учасник дискусії може додати до неї свою відповідь або прокоментувати вже наявні відповіді. Для того, щоб вступити в дискусію, користувач може просто переглянути теми дискусій і відповіді, які пропонуються іншими. Це особливо зручно для нових членів групи, для швидкого освоєння основних завдань, над якими працює група. Історія обговорення цих проблем зберігається в базі даних. Слухач також може зіграти й більш активну роль в обговоренні, пропонуючи свої варіанти відповідей, коментарі й нові теми для обговорення. У кожному електронному курсі система Moodle дає можливість створення декількох форумів;

- чат - система, призначена для організації дискусій і ділових ігор у режимі реального часу, користувачі системи мають можливість обмінюватися текстовими повідомленнями, доступними як усім учасникам дискусії, так i окремим учасникам на вибір;

- опитування - для проведення швидких опитувань і голосувань. Задається питання й визначаються кілька варіантів відповідей;

- анкета - відібрано кілька типів анкет, особливо корисних для оцінки інтерактивних методів дистанційного навчання.

Концепція безперервного професійного розвитку (БПР) фармацевтичних працівників є невід'ємною складовою прийнятих на рівні Всесвітньої організації охорони здоров'я (World Health Organization - WHO) та Міжнародної фармацевтичної федерації (International Pharmaceutical Federation — FIP) стандартів з належної практики фармацевтичної освіти (Good Pharmacy 
Education Practice - GPEP) та належної аптечної практики (Good Pharmaceutical Practice - GPP) [6].

До нормативно-правової бази, яка стосується концепції БПР відносяться документи [7-10].

- Постанова КМУ від 28 березня 2018 р. №302. Про затвердження Положення про систему безперервного професійного розвитку фахівців у сфері охорони здоров'я;

- $\quad$ Постанова Кабінету Міністрів від 14.07.2021 р. №725 «Про затвердження Положення про систему безперервного професійного розвитку медичних та фармацевтичних працівників»;

- Наказ MO3 від 22.02.2019 р. №446 «Деякі питання безперервного професійного розвитку лікарів»;

- Наказ MO3 від 18.05.1994 р. №73 «Деякі питання безперервного професійного розвитку лікарів».

На сьогодні у вітчизняних фахівців фармації майже повністю відсутні будь-які мотиваційні стимули щорічно набирати бали БПР та підвищувати свою кваліфікацію на циклах тематичного удосконалення (ТУ) з актуальних проблем фармації, що пропонуються закладами вищої медичної (фармацевтичної) освіти. Як правило, нинішні фахівці, переважна більшість яких працює у приватному секторі, задовольняються лише проходженням раз на 5 років місячного циклу стажування, необхідного для підтвердження статусу «провізора-спеціаліста» та отримання відповідного сертифіката, що даватиме право працювати за фахом упродовж наступних 5 років та $є$ дотриманням мінімальних кваліфікаційних вимог до провізорів аптечних закладів, визначених п.п. 148 та 181 Ліцензійних умов провадження господарської діяльності з виробництва лікарських засобів, оптової та роздрібної торгівлі лікарськими засобами, імпорту лікарських засобів (крім активних фармацевтичних інгредієнтів), затверджених постановою КМУ від 30.11.2016 р. №929 «Про затвердження Ліцензійних умов провадження господарської діяльності з виробництва лікарських засобів, оптової та роздрібної торгівлі лікарськими засобами, імпорту лікарських засобів (крім активних фармацевтичних інгредієнтів)» (зі змінами) [11].

Мета. Привести особливості навчання на тематичному циклі «Загальна фармація на засадах фармацевтичного права» для фахівців фармації під час пандеміï Covid-19 (штами «Дельта», «Омікрон»).

Матеріали та методи дослідження. У роботі було опрацьовано навчально-методичні матеріали Кафедри ХМАПО та кафедри організації та економіки фармації, технології ліків та біофармації ЛМІ, методичні розробки до лекційних, семінарських та практичних занять. Також було приведено особливості викладання на циклі тематичного удосконалення (ТУ) «Загальна фармація на засадах фармацевтичного права». Для досягнення поставленої мети використовувалися методи документального, графічного та табличного методів аналізу, а також метод анкетування. Для дистанційного навчання використовували програму «Moodle». 
Проведені дослідження є фрагментом науково-дослідних робіт ТзОВ «Львівський медичний інститут» (ЛМІ) за темою «Удосконалення системи обігу ліків під час фармакотерапії на засадах доказової і судової фармації, організації, технології, біофармації та фармацевтичного права» (номер державної реєстрації 0120U105348, термін виконання 2021-2026), ХМАПО за темами «Удосконалення організаційно-правової процедури забезпечення ліками пацієнтів 3 позиції судової фармації, організації i управління фармацією» (номер державної реєстрації 0116U003137, термін виконання 20162020 рр.) та «Фармацевтичне та медичне право: інтегровані підходи до системи обігу ліків з позиції судової фармації та організації фармацевтичної справи» (номер державної реєстрації 0121 U000031, термін виконання 2021-2026рp.).

Результати дослідження та їх обговорення. Цикл тематичного удосконалення (ТУ) «Загальна фармація на засадах фармацевтичного права» проводиться для підвищення фахового рівня фахівців фармації з питань сучасного фармацевтичного законодавства, обігу лікарських засобів, правил відпуску рецептурних ліків, юридичної відповідальності фармацевтичних працівників тощо.

Метою циклу є отримання слухачами нових теоретичних знань і умінь 3 застосування норм фармацевтичного права у своїй практичній діяльності, пов'язаної 3 обігом лікарських засобів різних клініко-фармакологічних, номенклатурно-правових та класифікаційно-правових груп.

Цикл ТУ забезпечує кваліфіковану підготовку фахівців фармації, які займаються відпуском лікарських засобів в аптечних закладах та лікувальнопрофілактичних установах.

Зміст програми циклу «Загальна фармація на засадах фармацевтичного права» складається 3 трьох курсів: 1) Фармацевтичне право. Організація та управління фармацією. Порядок здійснення діяльності в сфері законного обігу лікарських засобів. Фармацевтичне право при виробництві та реалізації лікарських засобів; 2) Судова фармація. Фальсифіковані ліки. Юридична відповідальність фармацевтичних працівників за професійні порушення вимог чинного законодавства. Юридична опіка в системі правовідносин: лікарпацієнт-провізор-адвокат; 3) Доказова фармація. Технологія ліків, фармацевтичний аналіз, фармакогнозія, клінічна фармація, а також містить додаткові програми. Окрему увагу приділено навчальному матеріалу провізорів щодо пандемії COVID-19 (штами «Дельта», «Омікрон»). На платформі наявні теми:

- Organizational and legal study of quarantine restrictions in the spread of coronavirus disease in Ukraine. SSP Modern Pharmacy and Medicine. 2021. Vol.1. N. 2. P. 1-12. URL: https://doi.org/10.53933/sspmpm.v1i2.23 (In Ukrainian) [12];

- $\quad$ Experience of the department of medical and pharmaceutical law, general and clinical pharmacy of the Kharkiv medical academy of postgraduate education concerning the educational process during the quarantine period caused by COVID19. Actual Problems of Medicine and Pharmacy. 2021. Vol.2. N.2. P.1-20. URL: https://doi.org/10.52914/apmp.v2i2.33 (In Ukrainian) [13]; 
- $\quad$ Forensic pharmacy and medicine: risks for pharmacotherapy of addiction and countering of illegal circulation of psychoactive substances in the COVID-19 pandemic. 2021. SSP Modern Pharmacy and Medicine. Vol.1. N.2. P.1-28. URL: https://doi.org/10.53933/sspmpm.v1i2.32 (In Ukrainian) [14];

- Development of forensic and pharmaceutical researches within the organization of pharmaceutical business, drug technology and pharmaceutical law in Ukraine concerning the turnover of controlled drugs and substances. Health of Society. 2021. Vol. 10. N. 3. P. 98-106. DOI: https://doi.org/10.22141/23062436.10.3.2021.246351 (In Ukrainian) [15];

- $\quad$ Forensic and pharmaceutical research on the impact of drugs on the safety, life and health of road users within the organization of pharmaceutical business, drug technology, pharmaceutical and medical law in Ukraine. Health of Society. 2021. Vol. 10. N. 4. P. 127-132. DOI: https://doi.org/10.22141/23062436.10.4.2021.246355 (In Ukrainian) [16];

- $\quad$ Доказова фармація. Соціально небезпечні хвороби. COVID-19 [17, 18];

- $\quad$ Медичне та фармацевтичне право. Новітня термінологія сучасної освіти в умовах пандемії коронавірусу [19];

- $\quad$ Національні стратегії протидії коронавірусної хвороби (COVID-19);

- $\quad$ Стандарт фармацевтичної допомоги COVID 19;

- Про встановлення карантину та запровадження посилених протиепідемічних заходів на території із значним поширенням гострої респіраторної хвороби COVID-19, спричиненої коронавірусом SARS-CoV-2.

Упродовж циклу слухачі засвоять обсяг теоретичних знань та практичних навичок, необхідних для роботи з лікарськими засобами різних клінікофармакологічних, класифікаційно-правових та номенклатурно-правових груп.

Окрема увага приділена темі «Фармацевтичне право у регуляторній системі обігу лікарських засобів різних клініко-фармакологічних, номенклатурно-правових та класифікаційно-правових груп», що допоможе засвоїти слухачам загальні принципи та особливості відпуску із аптек всіх форм власності сильнодіючих, отруйних, психотропних, одурманюючих, наркотичних лікарських засобів, прекурсорів та комбінованих лікарських засобів [20-29].

Курси програми розбиті на розділи, кожний з яких включає теми, що складаються з окремих елементів. Для виконання програми в процесі навчання передбачені наступні види занять: лекції, семінари, практичні заняття. Всього на цикл виділяється 156 навчальних годин. Цикл включає додаткові програми: радіаційна медицина; особливо небезпечні інфекції; протидія насильству в сім'ї; імунопрофілактика, військово-медична підготовка.

Методичне забезпечення циклу тематичного удосконалення «Загальна фармація на засадах фармацевтичного права»: застосування бази Кафедри щодо законодавчих, нормативно-правових та інструктивно-методичних документів, що регулюють законний обіг лікарських засобів на фармацевтичному ринку; ситуаційне навчання (створення під керівництвом викладача проблемних ситуацій, які можуть зустрічатися у діяльності провізора, з подальшим 
роз'ясненням судово-фармацевтичної характеристики злочинів у фармації); проведення навчання в малих групах 3 пропозицією слухачу самостійно ознайомитися 3 питаннями правового регулювання трудових відносин, безрецептурного відпуску лікарських засобів, обігу оригінальних та генеричних лікарських засобів тощо [30-37].

Слухачам, які успішно склали іспит, видається посвідчення встановленого зразка про закінчення циклу тематичного удосконалення.

Перелік знань та умінь, якими повинні оволодіти слухачі циклу ТУ «Загальна фармація на засадах фармацевтичного права» [38-43]:

1. Навчитися визначати режим контролю лікарських засобів різних клінікофармакологічних, класифікаційно-правових та номенклатурно-правових груп.

2. Вивчити загальні принципи відповідальності за незаконний обіг всіх класифікаційно-правових груп лікарських засобів.

3. Вміти здійснювати предметно-кількісний облік лікарських засобів різних класифікаційно-правових та номенклатурно-правових груп в закладах охорони здоров'я.

4. Сформувати системні знання з правової та судової фармації стосовно питань контрольно-дозвільного регулювання фармацевтичної діяльності.

5. Оволодіти знаннями щодо загальних положень про право власності.

6. Оволодіти знаннями щодо міжнародного контролю та принципів боротьби із незаконним обігом засобів і речовин різних класифікаційноправових груп.

7. Ознайомитися $з$ кваліфікацією злочинів у сфері нелегального обігу сильнодіючих, отруйних, психотропних речовин, наркотичних та одурманюючих засобів і прекурсорів.

8. Навчитися здійснювати фармацевтичну опіку при відпуску лікарських засобів з аптек всіх форм власності та у лікувально-профілактичних закладах.

9. Засвоїти особливості обігу оригінальних та генеричних лікарських засобів.

10. Засвоїти особливості виготовлення та контролю якості екстемпоральних лікарських форм, які містять наркотичні засоби, психотропні, отруйні, сильнодіючі речовини та прекурсори.

11. Знати класифікацію психоактивних речовин (в тому числі лікарських засобів, що містять психоактивні речовини) та їх фармакологічні властивості (побічні реакції, протипоказання, взаємодія, зловживання, несумісність, тощо).

12. Знати особливості застосування лікарських засобів у різних контингентах пацієнтів.

13. Підняти рівень знань 3 медичної, фармацевтичної, юридичної, промислової етики, деонтології, правової культури та правосвідомості (ввічливість, чуйність, чутливість, співпереживання, доброта душі, терпимість, сердечність, скромність, доброзичливість, комунікабельність).

Для дистанційного навчання використовували програму «Moodle». Слухачі після електронної реєстрації отримували логіни та паролі для індивідуального входу на платформу і доступу до матеріалів для навчання. 
Приведено скріншоти навчально-методичних матеріалів на циклі ТУ «Загальна фармація на засадах фармацевтичного права» (Рис. 2-8).

Для слухача знайомство 3 циклом починається із привітання, а потім розмішено: силабус, алгоритм навчання, критерії оцінювання, форум «Допомоги тьютора та взаємодопомоги», форум «Знайомство», форум «Новини», глосарій «Новітня термінологія загальної фармації на засадах фармацевтичного права», інформація про цикли Кафедри та завідувача кафедри, програма циклу, література 3 гіперпосиланнями, рекомендована література, глосарій, базовий тест, список слухачів, розклад циклу.

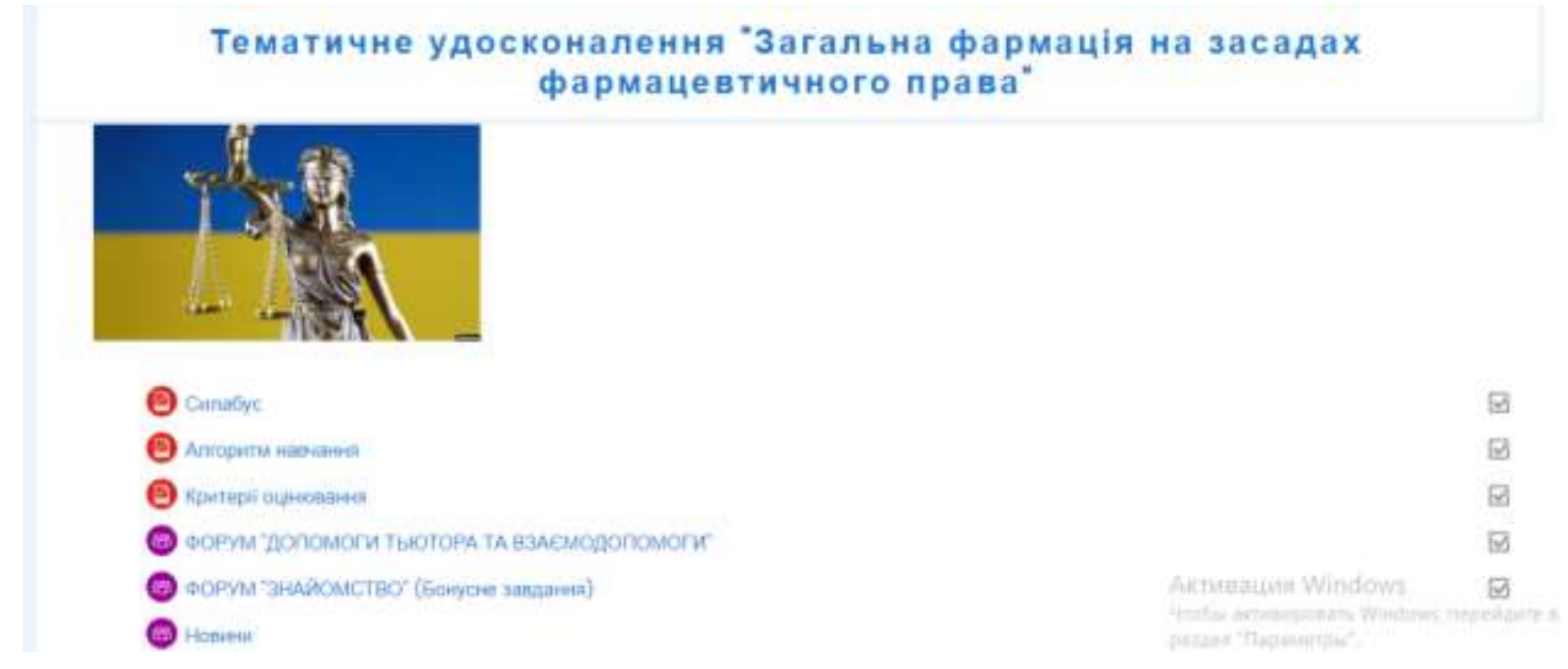

Рис. 2. Привітання слухачів циклу ТУ «Загальна фармація на засадах фармацевтичного права»

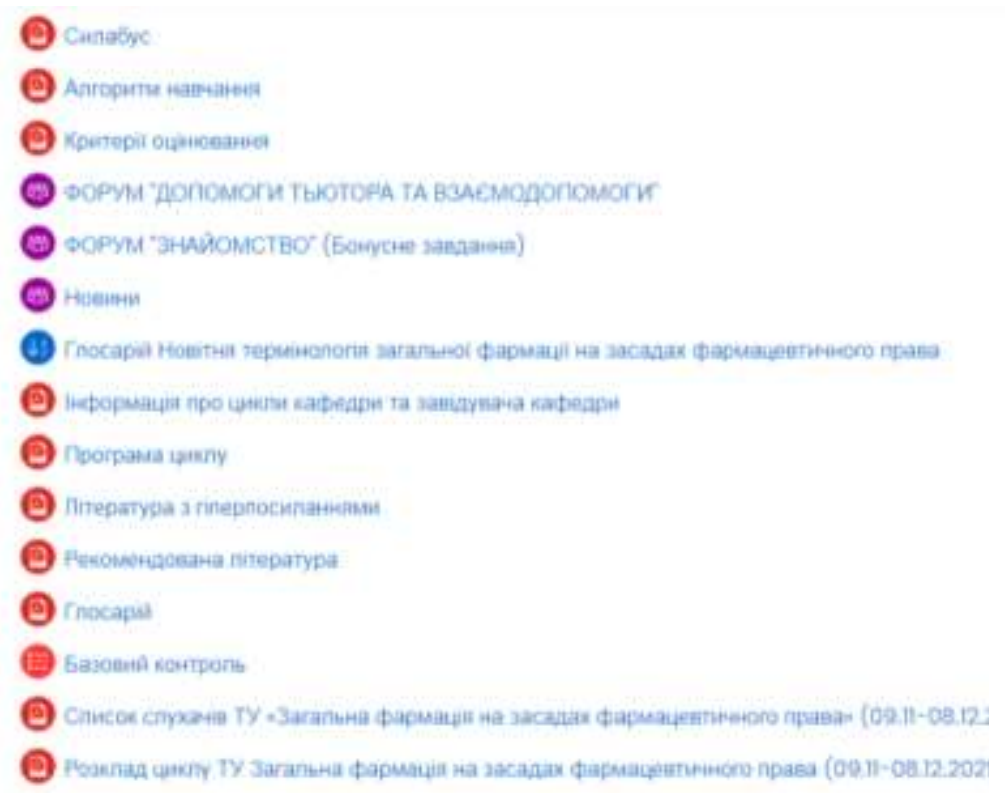

Рис. 3. Основна інформація циклу ТУ «Загальна фармація на засадах фармацевтичного права» 


\section{Секція 1}

Orpaniedtional And Legat Study of Quorantine Aestrictions in The Spread of Corontwirus Diseosen in Uivoime

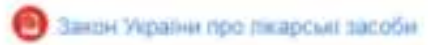

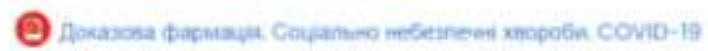

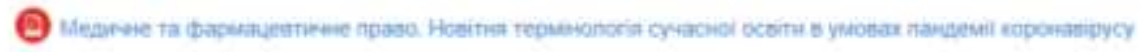

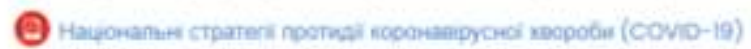

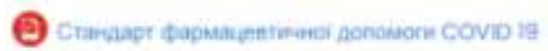

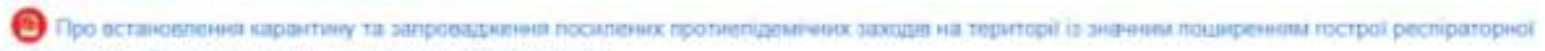

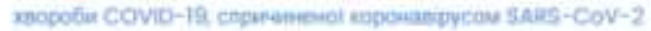

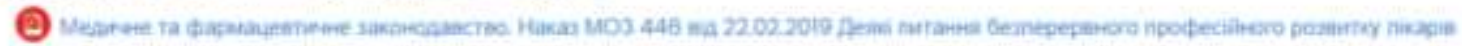

OP noniano rectysaim

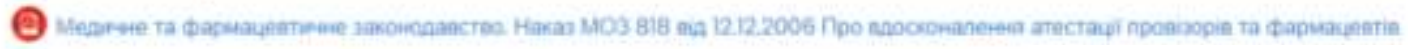

(2)

nonciesenta npo imepinarypy

\section{Рис. 4. Матеріали 1 секції до циклу ТУ «Загальна фармація на засадах фармацевтичного права»}

\section{Секція 2}

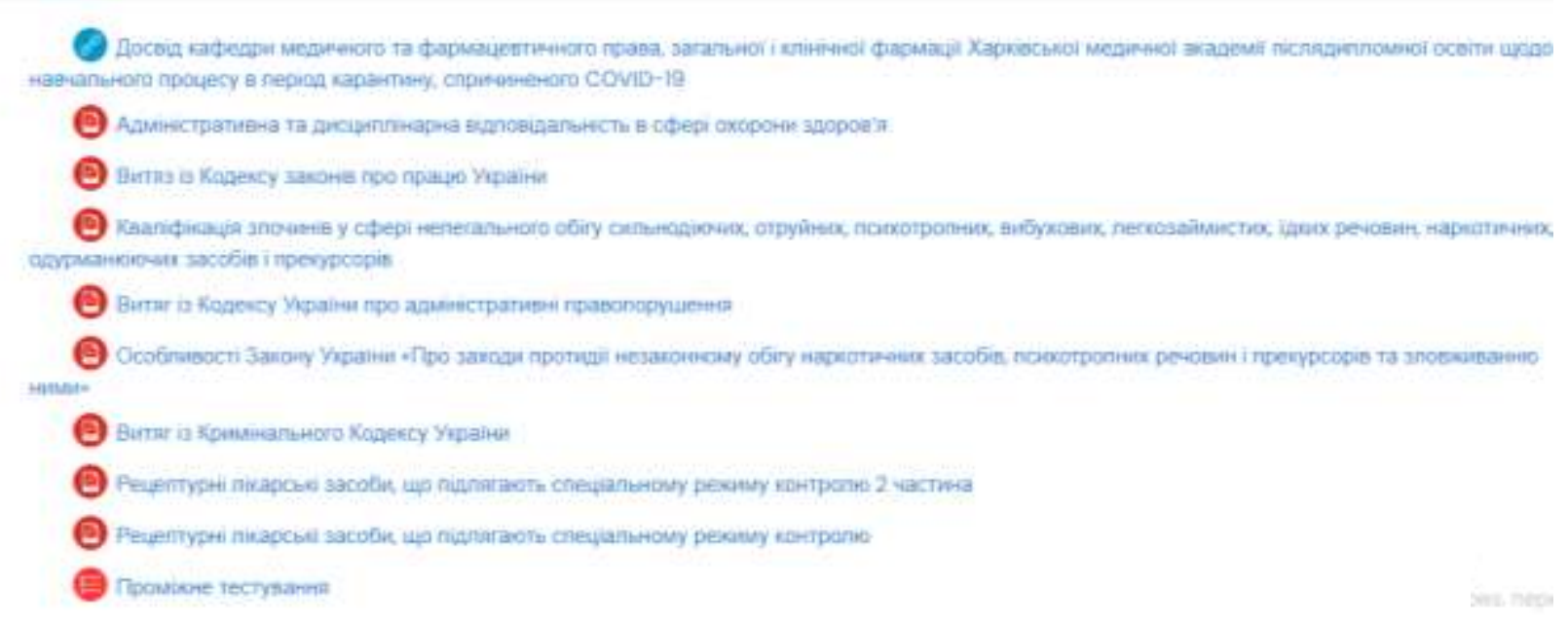

Рис. 5. Матеріали 2 секції до циклу ТУ «Загальна фармація на засадах фармацевтичного права»

\section{Секція 3}

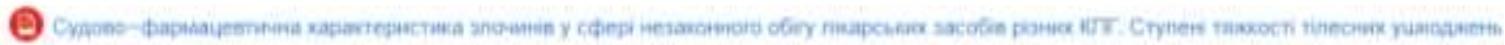
macrianc oroycien 73

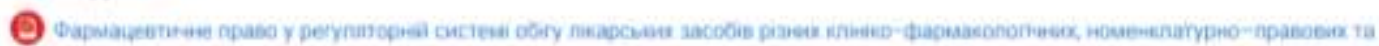

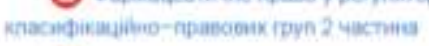

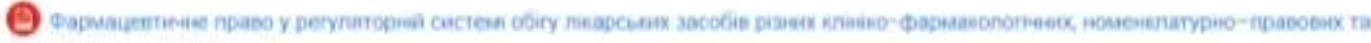
shacciquanjibmo-ripanosux rpyr

OPpomene recrymarme 
Рис. 6. Матеріали 3 секції до циклу ТУ «Загальна фармація на засадах фармацевтичного права»

\section{Секція 4}

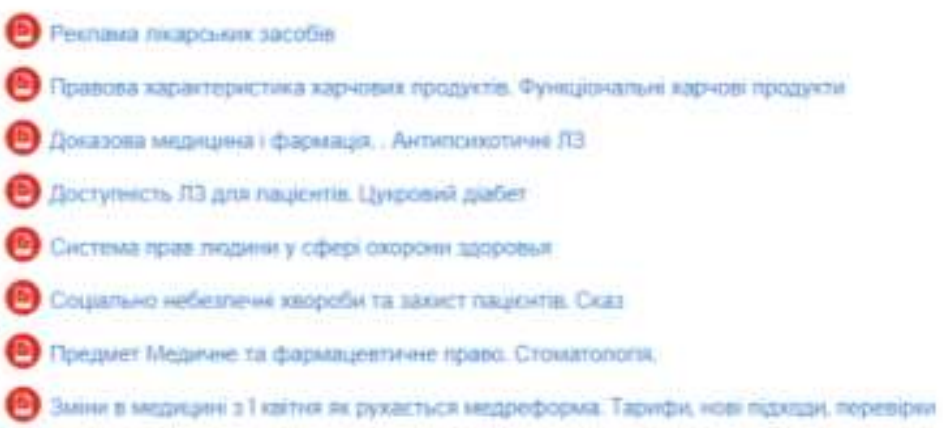

Рис. 7. Матеріали 4 секції до циклу ТУ «Загальна фармація на засадах фармацевтичного права»

\section{Заключне тестування}

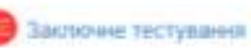

Рис. 8. Заключний тестовий контроль для завершення навчання на циклі ТУ «Загальна фармація на засадах фармацевтичного права»

Робота слухачів на платформі контролювалася викладачами Кафедри. Після завершення навчання слухачі заповнювали анкету, де 98\% вказали, що навчання було якісним, доступним, інформативним тощо.

Також слід вказати що Кафедрою для фахівців фармації проводяться курси за спеціальностями:

- «Загальна фармація» (цикл спеціалізації (інтернатури), передатестаційний цикл, стажування, тематичного удосконалення);

- «Клінічна фармація» (цикл спеціалізації (інтернатури), передатестаційний цикл, тематичного удосконалення);

- «Організація i управління фармацією» (цикл спеціалізації, передатестаційний цикл, стажування, тематичного удосконалення);

- «Аналітично-контрольна фармація» (цикл тематичного удосконалення, спеціалізації, передатестаційний цикл).

Для лікарів (лікувального, педіатричного i стоматологічного профілю) проводяться курси тематичного удосконалення:

- Медичне та фармацевтичне право в діяльності закладів охорони здоров'я;

- Основи медичного та фармацевтичного права в діяльності лікаря загальної практики - сімейної медицини;

- Медичне та фармацевтичне право у стоматології;

- Організаційно-правові аспекти ліцензування обігу лікарських засобів різних класифікаційно-правових груп у закладах охорони здоров'я; 
- Організація вхідного контролю якості лікарських засобів у закладах охорони здоров'я на основі медичного та фармацевтичного права;

- Медичне право в діяльності закладів охорони здоров'я;

- Сучасні тенденції медичного та фармацевтичного права в діяльності закладів охорони здоров'я;

- Особливості діяльності закладів охорони здоров'я під час карантину, спричиненого коронавірусом SARS-CoV-2;

Для провізорів проводяться курси тематичного удосконалення:

- Організація і управління фармацією на засадах фармацевтичного права;

- Загальна фармація на засадах фармацевтичного права;

- Фармацевтичне і медичне право в організації післядипломної освіти керівників провізорів-інтернів;

- «Оптимізація діяльності закладів охорони здоров’я на засадах фармацевтичного права».

Як відмічає Вороненко Ю.В., саме фахівці медицини та фармації продовжують працювати у дуже складних умовах [44] пандемії на «COVID19», яка суттєво впливає на якість та попит освітніх послуг, що надають заклади вищої освіти. Також це стосується тих форм навчання, де основну роль грають медичні практичні навички: інтернатура, спеціалізація, стажування, майстер-класи, симуляційні тренінги. Але безумовним залишається виконання в системі правовідносин «лікар-пацієнт-провізор» законів i нормативноправових актів, тобто норм медичного та фармацевтичного права [45], якими встановлено жорсткі карантинні протиепідемічні заходи, невиконання яких мають судово-фармацевтичні та кримінально-правові ризики [46-54]. Сьогодні це - не єдина проблема, яка заважає ефективно працювати і розвиватися медичній та фармацевтичній освіті, тобто є ще три виклики, які одночасно негативно протидіють дійсно самовідданій освітянській праці, які саме органам державної влади та самоврядування необхідно вирішувати.

Висновки. Пандемія COVID-19 (штами «Дельта», «Омікрон) сприяла оптимізації роботи в режимі он-лайн, що вимагало освоєння нових навичок роботи в мережі Інтернет та додаткового навантаження на професорськовикладацький склад Кафедри (індивідуальна праця із слухачами, інтернами в зручний для них час та вихідні дні тощо). Професорсько-викладацький склад та науковці Кафедри ХМАПО успішно проводить цикли 3 використанням технологій дистанційного навчання і 98\% слухачів задоволені пройденими курсами. Кафедра активно співпрацює з професорсько-викладацьким складом та науковцями ЛМІ та інших ВУЗів України, країн СНД та СС. Підкреслено, що розробка та просування національної стратегії вищої освіти з урахуванням світового досвіду здатна підвищити конкурентоспроможність вузів Україні на світовому освітньому ринку та задовольнити потреби національного та загальносвітового ринку праці.

Конфлікт інтересів. Автори засвідчують, що у них немає конфлікту інтересів. 


\section{Список літератури.}

1. Янко М., Дейнека О. Інтернатура під час пандемії. Як у Львові навчають майбутніх лікарів. Суспільне. 22.10.2021. URL: https://suspilne.media/173396internatura-pid-cas-pandemii-ak-u-lvovi-navcaut-majbutnih-likariv/.

2. MO3: інтерни і студенти самостійно не лікуватимуть хворих на COVID19. Радіо Свобода. 17.10.2020. URL: https://www.radiosvoboda.org/a/news-mozstudenty-covid/30898277.html.

3. Корда М. М., Шульгай А. Г., Машталір А. І., Чорномидз А. В. Дистанційне навчання - вимушений захід чи вимога часу (на прикладі Тернопільського національного медичного університету імені I. Я. Горбачевського МО3 України) // Актуальні питання вищої медичної (фармацевтичної) освіти: виклики сьогодення та перспективи їх вирішення : матеріали XVIII Всеукр. наук.-практ. конф. в онлайн-режимі за допомогою системи microsoft teams (Тернопіль, 20-21 трав. 2021 р.) / Терноп. нац. мед. ун-т імені І. Я. Горбачевського МОЗ України. - Тернопіль : ТНМУ, 2021. 3-13 с. 4. Що таке Moodle. URL: https://moodle.org/mod/page/view.php?id=8174

5. Інструкція користувача по роботі з системою управління дистанційним навчанням «Moodle» у Дніпропетровському державному університеті внутрішніх справ. URL: https://moodle.dduvs.in.ua/moodle.pdf

6. Убогов С. Законодавчі недопрацювання у сфері безперервного професійного розвитку провізорів. URL: https://www.apteka.ua/article/576368

7. Про затвердження Положення про систему безперервного професійного розвитку медичних та фармацевтичних працівників: Постанова Кабінету Міністрів від 14.07.2021 p. №725. URL: https://www.kmu.gov.ua/npas/prozatverdzhennya-polozhennya-pro-sistemu-bezperervnogo-profesijnogo-rozvitkumedichnih-ta-farmacevtichnih-pracivnikiv-725-140721

8. Деякі питання безперервного професійного розвитку лікарів. Наказ МО3 від 22.02.2019 р. № 446. URL: https://zakon.rada.gov.ua/laws/show/z0293-19\#Text 9. Деякі питання безперервного професійного розвитку лікарів. Наказ МО3 від 18.05.1994 p. № 73 URL: https://zakon.rada.gov.ua/laws/show/z0293-19\#Text 10. Про затвердження Положення про систему безперервного професійного розвитку фахівців у сфері охорони здоров'я: Постанова КМУ від 28.03.2018 р. № 302. URL: https://zakon.rada.gov.ua/laws/show/302-2018-п\#Text

11. Про затвердження Ліцензійних умов провадження господарської діяльності з виробництва лікарських засобів, оптової та роздрібної торгівлі лікарськими засобами, імпорту лікарських засобів (крім активних фармацевтичних інгредієнтів)». Постанова КМУ від 30.11.2016 p. № 929. URL: https://zakon.rada.gov.ua/laws/show/929-2016-ח

12. Shapovalov V., Butko L., Shapovalov V. Organizational and legal study of quarantine restrictions in the spread of coronavirus disease in Ukraine. SSP Modern Pharmacy and Medicine. 2021. Vol. 1. N. 2. P. 1-12. URL: https://doi.org/10.53933/sspmpm.v1i2.23.

13. Shapovalova B., Shapovalov B., Shapovalov B., Osyntseva A., Nehretskii C., Derkach A., Sichkarenko O., Bychkova T. Experience of the department of medical 
and pharmaceutical law, general and clinical pharmacy of the Kharkiv medical academy of postgraduate education concerning the educational process during the quarantine period caused by COVID-19. Actual Problems of Medicine and Pharmacy. 2021. Vol.2. N.2. P. 1-20. https://doi.org/10.52914/apmp.v2i2.33 (In Ukrainian)

14. Hayduchok I., Shapovalov V. Forensic pharmacy and medicine: risks for pharmacotherapy of addiction and countering of illegal circulation of psychoactive substances in the COVID-19 pandemic. 2021. SSP Modern Pharmacy and Medicine . Vol. 1. N. 2. P. 1-28. URL:https://doi.org/10.53933/sspmpm.v1i2.32 (In Ukrainian)

15. Shapovalov V.V. (Jr.), Shapovalova V.A., Shapovalov V.V. Development of forensic and pharmaceutical researches within the organization of pharmaceutical business, drug technology and pharmaceutical law in Ukraine concerning the turnover of controlled drugs and substances. Health of Society. 2021. Vol. 10. N. 3. P. 98-106. doi:https://doi.org/10.22141/2306-2436.10.3.2021.246351 (In Ukrainian)

16. Shapovalov V.V. (Jr.), Shapovalova V.A., Shapovalov V.V. Forensic and pharmaceutical research on the impact of drugs on the safety, life and health of road users within the organization of pharmaceutical business, drug technology, pharmaceutical and medical law in Ukraine. Health of Society. 2021. Vol. 10. N. 4. P. 127-132. doi: https://doi.org/10.22141/2306-2436.10.4.2021.246355 (In Ukrainian)

17. Coronavirus disease pandemia 2019: growth of epidemic dangers / V.O. Shapovalova, S.I. Zbrozhek, V.V. Shapovalov, V.V. Shapovalov. Acta scientific pharmaceutical sciences. 2020. V. 4. Issue 7. P. $61-68$.

18. Owen P. Hall. Editorial: COVID-19 and the Future of Management Education. 2020. Vol. 23. Is.1. P. 1-12.

19. Шаповалова В.О., Шаповалов В.В., Осинцева А.О., Шаповалов В.В. Оновлення медичного глосарію на засадах фармацевтичного права та доказової фармації. Сучасні напрямки удосконалення фармацевтичного забезпечення населення: від розробки до використання лікарських засобів природного i синтетичного походження: матеріали науково-практичної дистанційної конференції з міжнародною участю, присвяченої 75-й річниці Університету та 20-й річниці створення фармацевтичного факультету, м. Івано-Франківськ, 1920 травня 2020 р. Ів.-Фр., 2020. С. 71-72

20. Shapovalova V.O., Shapovalov V.V., Shapovalov V.V. et al. Distance teaching of medical and pharmaceutical law in the system of postgraduate education of doctors and pharmacists in quarantine conditions. Organization of scientific research in modern conditions 2020: conference proceedings. Seattle: KindleDP in conjunction with the «ISE\&E» \& SWorld, 2020. P. 180-184. URL: https://www.sworld.com.ua/konferus02/sbor-us2.pdf.

21. Shapovalov V.V., Shapovalova V.O., Shapovalov V.V. et al. Medychne ta farmatsevtychne pravo: navch. posib. dlia dodyplomnoi ta pisliadyplomnoi formy navchannia. Seriia «Medychne ta farmatsevtychne pravo». 4-e vyd. zi zminamy ta dopovnenniamy. Kharkiv - Ivano-Frankivsk: KhMAPO, 2020. 128 s. 
22. Вивчення асортименту безрецептурних лікарських засобів, що знаходяться в обігу на фармацевтичному ринку України, для фармакотерапії стресу у жінок / Шаповалова В.О., Шаповалов В.В., Радіонова В.О., Москаленко Д.В. // Инновационные подходы к развитию медицины, фармацевтики и эколого-биологических исследований : монография. - Одесса: КуприенкоСВ, 2015. - Р. 3. - С. 63-78.

23. Инновационные подходы к развитию медицины, фармацевтики и эколого-биологических исследований : монография / [авт. кол. : Акуленко С.В., Березовская Г.Б., Бовікина Г.А., Богданова А.С., Буряк М.В., Вильданова Р.Р., Володина В.П., Горшкова Л.М., Ефремова М.И., Князева М.В., Колесов С.В., Куковинец О.С., Курило А.А., Малов А.А., Москаленко Д.В., Радионова В.А., Семенов К.А., Сигаева Н.Н., Титова С.В., Улитин И.Б., Улитина Е.П., Федоров А.А., Хохленкова Н.В., Чирикова Н.К., Шандиба О.Б. Шаповалов В.В., Шаповалова В.А., Шпетний Д.М., Ярных Т.Г. - Одесса: КуприенкоСВ, 2015. 192 с.; С. 63-78 : ил., табл. - ISBN 978-966-2769-71-5.

24. Медичне та фармацевтичне право: контент-аналіз обігу лікарських засобів в закладах охорони здоров'я на принципах формулярної системи : метод. реком. / [В.В. Шаповалов (мол.), О.О. Рищенко, В.В. Шаповалов, В.О. Шаповалова, Н.М. Рязанцева, М.О. Хмелевський]. - Х., 2014. - 24 с.

25. Міжнародні стандарти управління якості як основа для запобігання розповсюдження неякісної та фальсифікованої продукції : навчальнометодичний посібник для самостійної роботи / В.В. Шаповалов, Л.О. Комар Харків: ХМАПО, 2016. - 90 с.

26. Наркологія: Національний підручник з грифом МOH та MO3/ Сосін I.К., Чуєв Ю.Ф., Артемчук А.П., Бурмака Н.П., Волков О.С., Гончарова О.Ю., Дворяк О.В., Друзь О.В., Лінський І.В., Мисько Г.М., Мінко О.І., Мішиєв В.Д., Овчаренко М.О., Сквіра I.М., Слабунов О.С., Чайка С.В., Шаповалова В.О., Шаповалов В.В., Шаповалов В.В. (мол.); за ред. І.К. Сосіна, Ю.Ф. Чуєва. - Х.: Вид-во "Колегіум", 2014. - 1440 с.

27. Онкоепідеміологія в Україні: сучасний стан, категорії хворих, особливості обігу лікарських засобів з позиції фармацевтичного права: метод. реком. / Шаповалова В.О., Шаповалов В.В. (мол.), Куликова О.В., Шаповалов В.В. - Харків, 2016. -28 с.

28. Оригінальні та генеричні лікарські засоби : навчально-методичний посібник для самостійної роботи / В. О.Шаповалова, В. В. Шаповалов, А. О. Осинцева. - Харків : ХМАПО, 2016. - 37 с.

29. Порядок контрольно-дозвільного обігу прекурсорів на засадах фармацевтичного права : навч. посіб. з грифом МОН (серія: Фармацевтичне право) / В.О. Шаповалова, В.В. Шаповалов, В.В. Шаповалов (мол.), Н.Г. Малініна, О.В. Пересипкін; за заг. ред. В.В. Шаповалова. - Х., 2011. - 56 с.

30. Режим контролю анальгетичних лікарських засобів у фармакотерапії больового синдрому різного генезу в учасників бойових дій, які брали участь в антитерористичній операції : інформаційний лист про нововведення / [B. В. Шаповалов (доц.), В. О. Шаповалова, В. В. Шаповалов, О. В. Рогожнікова]. - 
Уст.-розробн.: ХМАПО МОЗ України, Укрмедпатентінформ МОЗ України. К.: Укрмедпатентінформ МОЗ України, 2016. - №219-2016, вип. 13. - 5 с.

31. Режим контролю екстемпорального лікарського засобу для лікування синдрому відміни алкоголю : інформаційний лист про нововведення / [В. О. Шаповалова, С. I. Зброжек, I. К. Сосін, В. В. Шаповалов (доц.), В. В. Шаповалов, А. О. Осинцева]. - Уст.-розробн.: ХМАПО МОЗ України, Укрмедпатентінформ МОЗ України. - К.: Укрмедпатентінформ МОЗ України, 2016. - №218-2016, вип. 12. - 5 с.

32. Режим контролю лікарських засобів різних класифікайційно-правових груп. Комбіновані лікарські засоби : навчально-методичний посібник для самостійної роботи / В.В. Шаповалов, Л.О.Комар, В.О. Омельченко. - Х.: ХМАПО, 2017. $-26 \mathrm{c}$.

33. Режим контролю ферментних лікарських засобів у фармакотерапії панкреатиту у осіб з синдромом відміни алкоголю: інформаційний лист про нововведення / В.В. Шаповалов (доц.), І.К. Сосін, В.О. Шаповалова, В.В. Шаповалов, А.Г. Мовсісян. - Уст.-розробн.: ХМАПО МОЗ України, Укрмедпатентінформ МОЗ України. - К.: Укрмедпатентінформ МОЗ України, 2016. - №139-2016, вип. 3. - 4 с.

34. Система надання медико-фармацевтичної допомоги наркохворим жінкам на регіональному рівні : метод. реком. / [В.О. Радіонова, Шаповалова В.О., Шаповалов В.В., Капєльнікова Є.В.]. - Х., 2014. - 36 с. (Серія: Медичне та фармацевтичне право).

35. Склад та режим контролю екстемпорального лікарського засобу для лікування дерматологічних захворювань: інформаційний лист про нововведення / В.О. Шаповалова, В.В. Шаповалов, Ю.В. Васіна, К.І. Ковальова. - Уст.-розробн.: ХМАПО МОЗ України, Укрмедпатентінформ МОЗ України. К.: Укрмедпатентінформ МОЗ України, 2015. - №164-2015, вип. 3. - 4 с.

36. Склад та режим контролю екстемпорального лікарського засобу для фармакокорекції больового синдрому онкологічного генезу : інформаційний лист про нововведення / [В. О. Шаповалова, В. В. Шаповалов (доц.), В. В. Шаповалов, О. В. Куликова, Л. О. Комар]. - Уст.-розробн.: ХМАПО МОЗ України, Укрмедпатентінформ МО3 України. - К.: Укрмедпатентінформ МО3 України, 2016. - №254-2016, вип. 7. - 5 с.

37. Склад та режим контролю екстемпорального лікарського засобу седативної дії : інформаційний лист про нововведення / [В. О. Шаповалова, В. В. Шаповалов, І. К. Сосін, В. В. Шаповалов (доц.), Д. В. Москаленко, Л. О. Комар]. - Уст.-розробн.: ХМАПО МОЗ України, Укрмедпатентінформ МОЗ України. - К.: Укрмедпатентінформ МОЗ України, 2016. - №220-2016, вип. 14. $-6 \mathrm{c}$.

38. Уніфіковані програми 3 фармацевтичного та медичного права (фармацевтичного, медичного законодавства, судової фармації та доказової фармації) / Шаповалов В.В., Шаповалов В.В. (мол.), Шаповалова В.О., Галацан О.В., Васіна Ю.В., Малініна Н.Г., Радіонова В.О., Курижева О.О., Омельченко В.О., Лебедєва Т.О., Мовсісян А.Г. - Х.: Фактор, 2012. - 100 с. 
39. Фармацевтическое и медицинское право: уч. пособ. (серия: Фармацевтическое право) / В.В. Шаповалов, В.В. Шаповалов (мл.), В.А. Шаповалова; под ред. В.В.Шаповалова. - [1-е изд.]. - Х.: Изд-во «Скорпион», 2011. - $208 \mathrm{c}$.

40. Фармацевтична опіка хворих з патологією шлункового тракту: навчальнометодичний посібник для самостійної роботи / В.О. Шаповалова, Г.В. Бондарчук, Л.О. Комар. - Харків : ХМАПО, 2016. - 36 с.

41. Фармацевтичне право : навч. посіб. / В.О. Шаповалова, В.В. Шаповалов, В.В. Шаповалов (мол.), О.С. Абросимов, Ю.В. Васіна, В.О. Радіонова, Н.Г. Малініна, О.О. Курижева; за заг. ред. В.О. Шаповалової [ЕЛЕКТРОННИЙ РЕСУРС]: інтеракт. підруч. - [3-є вид.]. - Х., 2011. - 1 електрон. оптик. диск (CD-ROM). - Систем. вимоги: Windows XP, Vista, 7, Mac OS X, Ubuntu, 512 Mb RAM, CD-ROM. - Назва $з$ титул. екрану.

42. Шаповалов В. В. Юридичний супровід в системі правовідносин «лікар»«наркозалежна особа» - «провізор» у програмах замісної підтримувальної терапії в Україні : метод. реком. 3 грифом MO3 (68.15/365.15) / В. В. Шаповалов, І. К. Сосін, С. В. Капєльнікова. - Х., 2015. - 28 с.

43. Навчальний план та програма циклу тематичного удосконалення «Загальна фармація на засадах фармацевтичного права» / Шаповалова В.О., Шаповалов В.В., Шаповалов В.В., Радіонова В.О., Негрецький С.М., Осинцева А.О., Комар Л.О., Тарасова І.В. - Х.: ХМАПО, 2017. - 11 с.

44. Вороненко Ю.В. Вітальне слово// Безперервний професійний розвиток лікарів та провізорів в умовах реформування системи охорони здоров'я (9 жовтня 2020 року). MO3 України, Національна медична академія післядипломної освіти імені П. Л. Шупика.- Київ : НМАПО імені П. Л. Шупика, 2020.- C. 24-25. URL: https://nmapo.edu.ua/zagruzka2/CPD_conference_NMAPO_2020

45. Шаповалов В. В., Шаповалов В. В., Шаповалова В. А., Омельченко В. О. Вивчення міждисциплінарних зв'язків кримінально-правових та судовофармацевтичних норм у системі обігу лікарських засобів //Теорія і практика правознавства, 2017. - Вип. 1 (11). -9 с. URL: https://dspace.nlu.edu.ua/bitstream/123456789/16367/1/11.

46. Токсикологічні та судово-фармацевтичні критерії щодо розмежування лікарських засобів до різних категорій / I.M. Трахтенберг, В. О. Шаповалова, О.П. Вікторов та інш. Фармація XXI століття: Тез. доп. Всеукр. наук.-практ. конф., 23-24 жовт. 2002 р. Х., 2002. - С. 198-199.

47. Forensic and pharmaceutical status of the determination of depending from cannabinoids (F12) / Shapovalov V.V. (Jr.), Shapovalova V.A., Shapovalov V.V., Negretsky S.N. // European Applied Sciences. - 2013. - ISSN 2195-2183. - Vol. 2, № 9. - P. 146-149.

48. Шаповалов В.В., Шаповалов В.В. (мл.), Шаповалова В.А. и др. Судебнофармацевтическое изучение врачебных ошибок при осуществлении оборота лекарственных средств и оказании помощи больным, страдающим злокачественными новообразованиями // Научные ведомости БелГУ. Сер. 
Медицина. Фармация, 2017. - №12 (261), вып.38. - C. 130-140. URL: http://dspace.bsu.edu.ru/handle/123456789/23850.

49. Шаповалов Валентин В., Шаповалов В.В., Шаповалова В.О., Рогожнікова О.В. Судово-фармацевтичні ризики: неналежне виконання професійних обов'язків медичним або фармацевтичним працівником, що заважає забезпеченню лікарськими засобами пільгового контингенту на основі фармацевтичного права //Теорія і практика правознавства, 2014. - Вип 2 (6). URL: http://tlaw.nlu.edu.ua/article/view/63579.

50. Шаповалова В.О, Шаповалов Валентин В., Шаповалов В.В. та інш. Викладання медичного і фармацевтичного права в системі післядипломної освіти лікарів i провізорів // Здобутки та перспективи управління фармацевтичною системою: збірник праць науково-практичної конференції 3 міжнародною участю, присвяченої 90-річчю з дня народження професора Р. М. Піняжка і 75-річчю з дня народження професора О. Л. Грома (м. Львів, 28 - 29 вересня 2018 р.) : наукове видання; за редакцією Богдана Громовика та Артема Горілика. - Львів : Ліга-Прес, 2018. С. 156-160.

51. Шаповалов В.В., Шаповалова В.А., Петренко С.Л. Использование результатов оперативно-розыскной деятельности отделов по борьбе с наркотиками в процессе преподавания предмета «Правовая и судебная фармація» для укрепления национальной безопасности //Зб. наук. праць: «Актуальні проблеми медичної науки». - Х.: «Око», 1998. - С. 323-327.

52. Tukhar I., Shapovalova V., Shapovalov V., Shapovalov V. Pharmacological view on the problem of comorbidity in the pharmacotherapy of chronic pancreatitis. Science Review. Vol. 3. No. 38. P. 1-5. DOI: 10.31435/rsglobal_sr/30072021/7591

53. Шаповалова В. О., Гайдучок І. Г., Іщейкін К. С., Шаповалов В. В. (мол.), Шаповалов В. В. Свідоцтво про реєстрацію авторського права на твір. Україна. №106072. Фармакоекономічні підходи до фармакотерапії супроводу системних аутоімунних хвороб. (дата реєстрації 12.07.2021 р.). Заявка с202104126 від 22.07.2021 p.

54. Шаповалова В. О., Шаповалов В. В., Негрецький С М., Бутко А. Ю., Деркач А. І. Свідоцтво про реєстрацію авторського права на твір. Україна. №107818. Навчальний посібник для додипломної та післядипломної форми навчання «Збірник тестових завдань». (дата реєстрації 06.09.2021р.). Заявка с202105954 від 25.08.2021 p. 